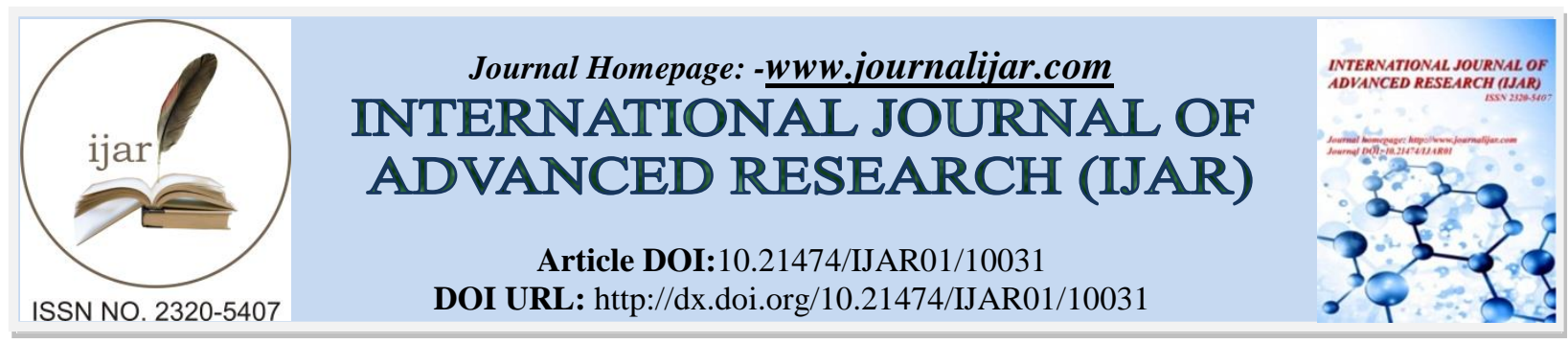

RESEARCH ARTICLE

\title{
ROLE OF BIOTECHNOLOGY IN DISEASE MANAGEMENT OF OIL SEEDS (MUSTARD).
}

\author{
Khushboo Dubey, Abhinav Mishra, Ratnesh Dubey and Sanghmitra. \\ Department of Plant Pathology, Department of BiotechnologyN. D. University of Agriculture and Technology, \\ Kumarganj, Faizabad -224229, U.P., India.
}

\section{Manuscript Info}

\section{Manuscript History}

Received: 10 September 2019

Final Accepted: 12 October 2019

Published: November 2019

Key words:-

major disease, Biotechnology tools, transgenic approaches.

\begin{abstract}
Indian mustard is one of the major rabi oilseed crop in India. Continuous improvement in rapeseed-mustard has resulted in nutritionally superior edible oil, and meal as an important source of protein in animal feed. The crop is affected by various biotic and abiotic stresses. There are many biotic stresses which affect the production of Mustard .Many attempts have been made by the scientists to improve Brassica using molecular markers like Amplified Fragment Length Polymorphism (AFLP), Simple Sequence Repeat (SSR), Single Nucleotide Polymorphism (SNP) based maps (Ramen et al., 2014) etc. Somaclonal variation as a tool for creating in vitro variability offers a unique opportunity for desirable attributes. Molecular markers such as Random Amplified Polymorphic DNA (RAPD), Restriction Fragment Length Polymorphism (RFLP), AFLP and SSR have been used for improving selection efficiency and selecting plant genotypes with the desired combinations of traits. Transgenic approaches have been followed to develop the transgenic for aphid resistance, male sterility, $\mathrm{AB}$ tolerance, herbicide resistance and drought tolerance. Bar, Barnase and Barstar based herbicide resistance and genetic male sterility have been used in the development of experimental hybrids.
\end{abstract}

Copy Right, IJAR, 2019,. All rights reserved.

\section{Introduction:-}

Brasssica juncea (L.) Czern \& Coss., also known by the name of Indian mustard, belongs to the family Brassicaceae (Syn. Cruciferae). The family currently includes 3709 species and 338 genera (Warwick et al., 2006) and is one of the ten most economically important plant families (Rich, 1991). Brassica juncea $(2 \mathrm{n}=36)$ is an amphidiploid species derived from interspecific cross between Brassica nigra $(2 \mathrm{n}=18)$ and B. rapa $(2 \mathrm{n}=20)$. Over the past couple of decades, these crops have become one of the most important sources of vegetable oil in the world. Continuous improvement in rapeseed-mustard has resulted in nutritionally superior edible oil, and meal as an important source of protein in animal feed. Rapeseed mustard crops are commercially cultivated in more than 60 countries and major produces include China, Canada, India, Australia, France, Germany, United Kingdom, Poland, Ukraine, Russia, USA and Czech Republic. The crop is affected by various biotic and abiotic tresses. There are many biotic stresses which affect the production of Mustard.

Corresponding Author:-Khushboo Dubey.

Address:-Department of Plant Pathology, Department of BiotechnologyN. D. University of Agriculture and Technology, Kumarganj, Faizabad -224229, U.P., India. 


\section{Major Diseases, Causal Agents and their Control in Managed Ecosystem}

Among various diseases, 4 diseases viz; Alternaria blight (Alternaria brassicae), White rust + Downy mildew complex (Albugo candida + Hyaloperonospora brassicae), white rot (Sclerotinia sclerotiorum) and Powdery mildew (Erysiphe cruciferarum) are of great economic importance. Among a number of other relatively less important diseases, seedling blights/ Damping-off (Rhizoctonia solani, Sclerotium rolfsii and Fusarium solani), Phyllody (caused by Sesame Phytoplasma), Bacterial rot (Xanthomonas campestris pv campestris), Club root (Plasmodiophora brassicae) and Mosaic (Turnip Mosaic Virus) appear to become important only under specific agro-ecological conditions in certain geographical areas and hence are assumed to be of regional and sporadic importance (Kolte, 1985).

\section{Damping off and Seedling Blight}

Many fungal species such as Alternaria, Fusarium, Phoma, and Rhizoctania solani are involved in causing seed rot and seedling blight. Among them, Rhizopus stolonifer is reported to be more important (Petrie, 1973). Disease occurs all around the world in Rapeseed-mustard. Damping-off can produce many symptoms ranging from preemergence rot (failure of plants to emerge) to post emergence damping-off (plants emerge and collapse at ground level). The pathogens involved in India, cause 6-15\% incidence (Khan and Kolte, 2002).

\section{Alternaria Blight:}

Alternaria blight or black spot, the most common, widespread and destructive disease is caused by Alternaria brassicae (Berk.) Sacc. infecting all above ground parts of the plant. In India, the disease is severe mainly in the states of Himachal Pradesh, Haryana, Rajasthan, Uttar Pradesh, Uttara Khand, Bihar and Madhya Pradesh, but appears in almost all the parts of the country. The symptoms of disease are formation of brown to black spots with concentric rings on leaves, stem and siliquae (Meena et al., 2010a).

\section{White Rust}

White rust, caused by Albugo candida (Pers. Ex Fr.) Kuntz. is an obligate pathogen of all cruciferous crops and reported to be infected by $A$. candida (Biga, 1955) all over the world.

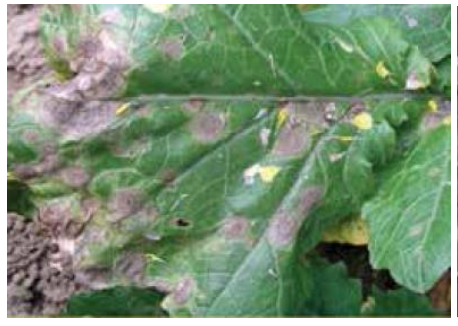

(1)

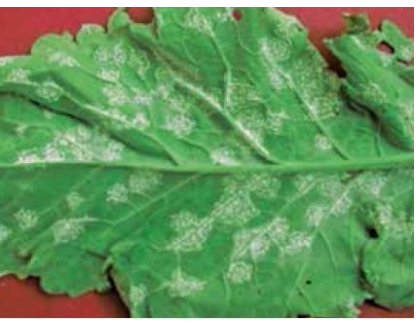

(2)

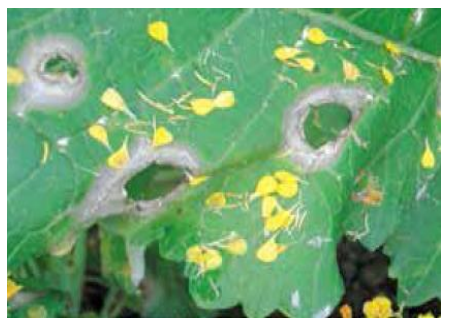

(3)

Fig1:-Showing the disease symptoms of (1) Alternaria Blight (2) White Rust (3) White Rot

Disease appearing on leaves is characterized by the appearance of white or creamy yellow raised pustules up to 2 $\mathrm{mm}$ in diameter, which later coalesce to form patches (Verma, 2012). The result in yield loss up to 47\% (Kolte, 1985).

\section{Sclerotinia Rot or White Rot:}

Rot of mustard caused by Sclerotinia sclerotiorum. The pathogen is Sclerotinia sclerotiorum (Lib.) de Bary. Mycelium is thin, $9-18 \mu \mathrm{m}$ in diameter with lateral branches of smaller diameter than the main hyphae. The sclerotia are black, round or semi spherical in shape measuring 3-10 $\mu \mathrm{m}$. One to several apothecia may grow from a single sclerotium. Ascospores discharged from the apothecia at the base of the plants in soil constitute important primary sources of infection.

\section{Powdery Mildew:}

Occurrence of powdery mildew on Rapeseed-mustard is reported from various parts of the world. Recent reports on the occurrence of powdery mildew of Rapeseed mustard deal with Erysiphe cruciferarum (Sharma, 1979). The symptoms appear in the form of dirty-white, circular, floury patches on both sides of lower leaves of the infected plants. The floury patches increase in size and coalesce to cover the entire stem and leaves under environmental conditions favourable to the pathogen. 


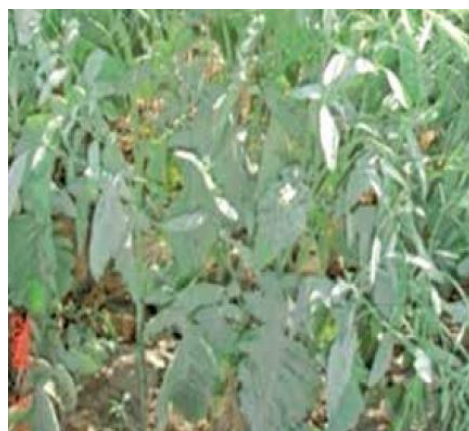

(4)

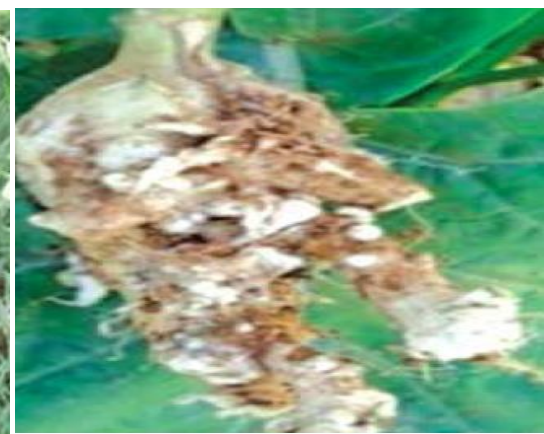

(5)

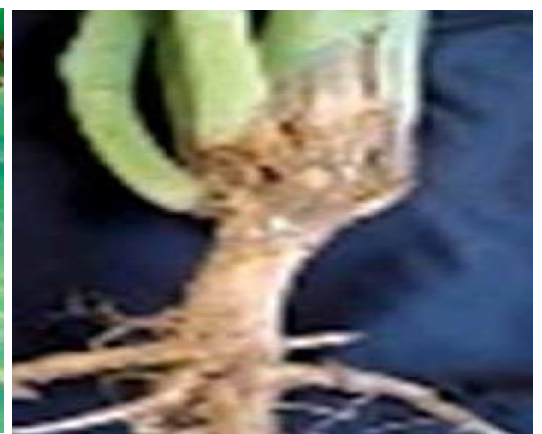

(6)

Fig 2:-Showing the disease symptoms of (4) Powdery Mildew (5) Club Root(6) Bacterial rot

\section{Club Root:}

Club root disease of the Brassicaceae has been a major threat to the crop caused by Plasmodiophora brassicae Woronin. Incidence and severity are greater in regions of extreme winters. The disease is reported to occur in East Germany, Malaya, New Zealand, Poland, Sweden, United Kingdom and the U. S. In India, the disease has been reported from hills of Darjeeling Nilgiri (Rajappan et al., 1999) on vegetable Brassicas. The disease has been reported from West Bengal and Orissa, respectively with losses in yield being up to 50\% (Laha et al., 1985; Chattopadhyay, 1991).

\section{Fusarium Wilt :}

Rapeseed-mustard is affected by Fusarium wilt caused by Fusarium oxysporum f. sp. conglutinans (Wr.) Snyder and Hansen. Distribution: The first authentic report of $F$. oxysporum f. sp. conglutinans as the cause of the disease in B. juncea was made from India by Rai and Singh (1973). Yield losses of greater than $30 \%$ are common. The affected plants show drooping, vein clearing and chlorosis of leaves, followed by wilting and drying, resulting in the death of the plant.

\section{Bacterial Stalk Rot}

The occurrence of stalk rot caused by Erwinia carotovora (Jones) Holland was reported first by Bhowmik and Trivedi (1980). On an average, about $60-80 \%$ of plants were affected by the disease in a farmer's field in Mahua Simpani village of Bharatpur district of Rajasthan (Meena et al., 2010b). The bacterium can infect Brassica oleracea var. Botrytis, Daucus carota, Lycopersicon esculentum and Nicotiana tabacum. Disease symptom: The disease is characterized by the appearance of water-soaked lesions on the collar region of plants, which are usually accompanied by a white frothing.

\section{Bacterial rot:}

The pathogen is Xanthomonas campestris pv. campestris (Pammel) Dowson. The black rot symptom on B. juncea was first observed in India by Patel et al. (1949). The disease is now reported to occur in a severe form in the State of Haryana (Vir et al., 1973; Gandhi and Parashar, 1978). Disease appears when the plants are two-months old. In the initial stages, dark streaks of varying length are observed either near the base of the stems or 8 to $10 \mathrm{~cm}$ above the ground level. These streaks gradually enlarge and girdle the stem.

\section{Application of Biotechnological tools in management of disease in Brassica:}

Biotechnological interventions have also been made in Indian mustard breeding programme. Many attempts have been made by the scientists to improve Brassica using molecular markers like Amplified Fragment Length Polymorphism (AFLP), Simple Sequence Repeat (SSR), Single Nucleotide Polymorphism (SNP) based maps (Ramen et al., 2014) etc. Abraham et al. (2000) at BARC Mumbai, reported somaclonal variants from mesophyll protoplast in B. juncea cv Rai 5 which showed 3-5 days early flowering. Commonly, some techniques e.g. tissue culture techniques to create somaclonal variation, anther culture to produce haploids and homozygous lines, protoplast culture and somatic hybridization, marker- assisted selection, development of transgenics for biotic and abiotic stresses have yielded promising results. Optimization of regeneration protocols have been 9. Biotechnological developments in Brassica achieved for most of the Brassica species using different explants such 
as cotyledons, hypocotyls, leaf segments and protoplasts, cotyledonary petiole and shoot apex (Verma and Singh 2007).

\section{Management of diseases of Mustard using tissue culture techniques:}

Somaclonal variation as a tool for creating in vitro variability offers a unique opportunity for desirable attributes. A somaclone of Varuna, BIO-902, has been released as a variety which possesses shattering resistance along with high yield (Katiyar and Chopra, 1995). Prakash et al., (2004) reported regeneration of normal plants by culturing anthers of CMS line of B. juncea carrying Diplotaxis erucoides cytoplasm. Somatic cell fusion of sexually incompatible species has also been made possible through production of somatic hybrids which have been utilized for transfer of desirable traits from parents to hybrids. Inter-specific hybrids were produced by fusing mesophyll protoplast of B. juncea and B. spinesceens (Kirti et al., 1991). Prakash et al. (1998) developed a male sterility and fertility restoration system in B.juncea by protoplast fusion with Moricandia arvensis.) These CMS lines were found to be chlorotic. Protoplast fusion of chlorotic male sterile $B$. juncea with green male sterile $B$. juncea resulted in green male sterile plants (Kirti et al., 1998).

\section{Management of diseases of Mustard using molecular marker technology and transgenic Approaches:}

Molecular markers such as Random Amplified Polymorphic DNA (RAPD), Restriction Fragment Length Polymorphism (RFLP), AFLP and SSR have been used for improving selection efficiency and selecting plant genotypes with the desired combinations of traits. Markers linked with white rust resistance (Prabhu et al., 1997), fatty acids, oil content, yellow seed colour and fertility restoration have been reported. Transgenic approaches have been followed to develop the transgenic for aphid resistance, male sterility, AB tolerance, herbicide resistance and drought tolerance. Bar, Barnase and Barstar based herbicide resistance and genetic male sterility have been used in the development of experimental hybrids (Jagannath et al,. 2002). Transgenics expressing Cod A (from A. glabiformis) gene for tolerance against abiotic stresses (salt and drought) have also been reported (Singh, 2003). Lectin gene for aphid resistance and DREB gene construct for drought tolerance are being used. Osmotin (from tobacco) for drought and salt tolerance, annexin gene for stress tolerance, Chitinase and Glucanase (from Arabidopsis) for tolerance to Alternaria blight disease and FAE1 gene for low erucic acid mustard cultivar are other transgenes being used in Rapeseed-mustard.

\section{References:-}

1. Abraham, V., Srinivasn, V.T. and Susan, E. 2000. Somaclonal variations in Indian mustard (B. juncea L.) plants derived from protoplasts. Tropical Agri. Res. Eaxt. 3: 131-132.

2. Biga, M.L.B. 1955. Review of the species of the genus Albugo based on the morphology of the conidia. Sydowia 9: 339-358.

3. Bhowmik, T.P. and Trivedi, B.M. 1980. A new bacterial stalk rot of Brassica. Current Sci. 49: $674-675$.

4. Chattopadhyay, A.K. 1991. Studies on the control of clubroot disease of rapeseed-mustard in West Bengal. Indian Phytopathol. 44: 397-398.

5. Gandhi, S.K. and Parashar, R.D. 1978. Evaluation of some fungicides and antibiotics against Xanthomonas campestris causing bacterial rot of raya. Indian Phytopathology. 31: 210.

6. Jagannath A, Arumugam N, Gupta V, Pradhan A,Verma PK and Pental D. 2002. Development of transgenic barstarlines and identification of a male sterile (barnase) /restorer (barstar) combination for heterosis breeding in Indian oilseed mustard (Brassica juncea). CurrentScience. 82:46-52.

7. Katiyar RK and ChopraVL. 1995. Asomaclone of Brassica juncea is processed in to a variety and is released for commercial cultivation in India. Cruciferae News letter. 17:92-7.

8. Khan, R.U. and Kolte, S.J. 2002. Some seedling diseases of rapeseed-mustard and their control. Indian Phytopathol 55: 102-103.

9. Kirti P B, Prakash Sand Chopra VL. 1991. Interspecific hybridization between B.juncea and B. spinescenes through proto plast fusion. Plant Cell Report. 9:639-42.

10. Kirti P B, Prakash S,Gaikwad K, Dinesh Kumar V, Bhat S R and Chopra VL. 1998. Chloroplast substitution overcomes leaf chlorosisina Moricandiaarvensis-based cytoplasmic male sterile B. juncea. Theor. Appl. Genet. 97:1179-82.

11. Kolte, S.J. 1985. Diseases of Annual Edible Oilseed Crops, Vol. II, Rapeseed-Mustard and Sesame Diseases. CRC Press Inc. Boca Raton, Florida, 135 pp.

12. Laha, J.N., Naskar, I. and Sharma, B.D. 1985. A new record of clubroot disease of mustard. Current Science. 54: 1247. 
13. Meena, P.D., Awasthi, R.P., Chattopadhyay, C., Kolte, S.J. and Kumar, A. 2010a.Alternaria blight: a chronic disease in rapeseed-mustard. J Rapeseed-mustard.1: 1-11.

14. Meena, P.D., Mondal, K., Sharma, A.K., Chattopadhyay, C. and Kumar, A. 2010b. Bacterial rot: a new threat for rapeseed-mustard production system in India. J Rapeseed-mustard1(1): 39-41.

15. Patel, M.K. Abhyankar, S.G. and Kulkarni, Y.S. 1949. Black rot of cabbage. Indian Phytopathology. 2: 58. Petrie, G.A. 1973. Diseases of Brassica species in Saskatchewan, 1970-72. III. Stem and root rots. Canadian Plant Disease Survey.53: 88-92.

16. Prabhu KV, Somens DJ, Rakow Gand Gugel RK.1997. Molecular markers linked to white rust resistance. Theor. Appl. Genet. 97:865-70. Prakash, S. and V.L. Chopra.

17. Prakash S, Bhat S R, Kirti P B, Banga S K, Banga S Sand Chopra V L. 2004. Rapeseed-mustardcrops in India: history and improvement. Brassica.6(3-4):1-54.

18. Prakash S, Kirti PB and Bhat SR. 1998. A Morican diaarvensis basedcyto plasmic male sterility and fertility restoration system in B.juncea. Theoretical Applied Genetics 97:488-92.

19. Rai, J.N. and Singh, R.P. 1973. Fusarial wilt of Brassica juncea. Indian Phytopathology.26: 225-232.

20. Rajappan, K.; Ramaraj, B. and Natarajan, S. 1999. Knol-khol - a new host for club-root disease in the Nilgiris. Indian Phytopathol.52: 328.

21. Ramen, H., Dalton-Murgan, J., Diffey, S., Almery, S., Edwards, D. and Balleuy, J. 2014. SNP markers-based map construction and genome-wide linkage analysis in Brassica napus. Plant Biotechnol. J. 12: 851-860.

22. Rich, TCG. 1991. Crucifers of Great Britain and Ireland. Botanical Society of the British Isles, London.3 36.

23. Sharma, A.K. 1979. Powdery mildew diseases of some crucifers from Jammu and Kashmir state. Indian J. Mycol. Plant Pathology, 9: 29-32.

24. Singh NB.2003. Accomplishment and challenges in rapeseed mustard researchBrassica3(3,4):1-11.

25. Verma R and Singh RR. 2007. Multiple shoot formation and in vitro flowering in B. juncea Var. Bhavani.Our Nature.5:21-4.

26. Verma, PR. 2012. White rust of crucifers: An overview of research progress. Journal of Rapeseed-mustard, 3(2): 78-87.

27. Vir, S., Kaushik, C.D. and Chand, J.N. 1973.The occurrence of bacterial rot of raya(Brassica junceacoss) in Haryana. PANS 19: 46-47. 